\title{
THE ROLE OF ZISWAF'S IN RESTRUKTURING INDONESIA ECONOMY IN COVID-19 ERA
}

\author{
${ }^{1}$ Muhammad Luqman Hakim*, ${ }^{2}$ Pria Mitra, ${ }^{3}$ Farras Nabila, ${ }^{4}$ Ahmad Al-Badawi, ${ }^{5}$ Maya Panorama \\ $1,2,3,4,5$ UIN Raden Fatah Palembang \\ Email: 1910602013@ radenfatah.ac.id*
}

\begin{abstract}
Zakat, Infaq, Shodaqoh, and Waqf (ZISWAF) have great potential in Indonesia, especially the majority of Indonesian religious people according to the Ministry of Home Affairs (June 2021), amounting to 86.88\% which is 236.53 million compared to 272.23 million. Based on the history when Umar Bin Abdul Aziz used ZISWAF, it was proven that ZISWAF was able to finance a country and its entire community. This research aims to provide solutions and the role of ZISWAF as one of the instruments of Sharia economy in dealing with the covid-19 pandemic. In this study, researchers used the Library Research approach method. From the data that has been mentioned that Indonesia will also advance not only on economic development and even able to make the people prosperous if ZISWAF is developed.
\end{abstract}

Keywords: Zakat, Infaq, Shodaqoh, Waqf (ZISWAF), Economy, Covid-19

\section{INTRODUCTION}

The covid-19 outbreak in 2020 resulted in an economic breakdown of the economic order of the community. Not only small traders are affected, but large companies also have to go out of business. There are 46 large companies that went bankrupt due to this outbreak (Detik.com, 2020). A wave of job cuts (layoffs) is rampant that resulted in many of the people losing income. According to the chairman of the Indonesian chamber of commerce (Ikadin) that workers who experienced layoffs reached 29 million people (Tribunnews.com 2020). Various initiatives from the government are carried out ranging from direct cash assistance (BLT) to Social assistance carried out; Pre-employment card with an aid value of Rp. 3,550,000 during the program, registered MSME Assistance worth 2.4 million rupiah, Salary subsidy with a nominal of 2.4 million rupiah, Cash Social Assistance worth 500 thousand rupiah, Electricity Subsidy for users under the minimum provisions and Pulse Money for ASN (Kompas.com 2020). But some of this assistance has not been able to maximally cope with the impact of the outbreak plus PSBB regulations that do not end, especially in big cities such as Jakarta, further aggravating the situation. Financial that began to thin and the availability of basic goods such as food is increasingly difficult to obtain making the community more squeezed. This situation is not new, in 1997/1998 Indonesia had experienced an economic crisis. High inflation resulted in the price of staples soaring and eventually society became uncontrolled thus disrupting security stability.

Indonesia is an agrarian country with rice as a staple food. This makes rice an important commodity in the scope of the national economy. The number of rice imports increased in 2014 by 21.9 million tons to 27.6 million tons in 2018 (Tempo.co, 2020). With this increase in import numbers, Indonesia is in the 62nd position on the 


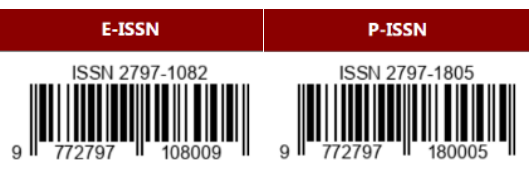

world food security index increased from position 65 in 2018 (GFSI 2019). But the increase in rice imports is not a good thing for the economy of farmers and the labor industry. Food is the right of every individual and the obligation of the state to guarantee its availability and in this context certainly not only rice, but there are also many other foods that need to be considered such as beef commodities that are mostly imports.

Relying on imports in maintaining national food stability must be investigated by increasing national food production in order to have a wider impact not only on food security but also economic resilience. Food scarcity can be caused by natural disasters, outbreaks or market distortions that result in price spikes in the market. This can be a trigger factor for social turmoil in society and eventually become a serious problem that threatens economic stability and national stability (Bulog 2014).

The discussion of food security not only talks about how the availability of food (production, import and storage) but its accessibility (distribution and ability of people to access food) must be considered. States must be able to ensure that people can meet their own food needs, or provide food that can be reached by all circles or provide assistance so that people can access their food needs. In a study entitled "contextualization of national food inventory management in an Islamic perspective" (Hakim 2018) explained that there is a disparity in supply and demand. Farmers conduct season-based production to reduce the cost and disruption of pests. This results in an increase in the level of disparity so that food prices fall during the harvest season and rise outside the harvest season. This research focuses on management of post-harvest management namely Bulog and good distribution on warehouse receipts.

Another study titled "a paradox between the food crisis and the irony of food security" (Maryatin and Subiyanto 2014) explains how a food crisis occurs amid food availability. This study provides an overview that a country can have food security or adequate food availability but is not accessible to the public. Or easy access but unaffordable prices. This study explains the difference in viewpoints of conventional food security and food security according to Islam.

In this study, the authors tried to include zakat, infak, alms and waqf (ZISWAF) instruments as food security solutions in times of crisis. In difficult times like today, it becomes a momentum for some Muslims who have excess wealth to help ease the burden of their brothers affected by the outbreak in the form of ZISWAF. ZISWAF is an Islamic sharia that is commanded by Allah SWT as a means of distributing property (halal) so as not to rotate among the rich (QS Al Hashim: 7). Zakat itself is a sharia that is clearly explained subject and object (QS At Taubah: $60)$ with poor and poor as the two main priority groups.

This research was conducted so that ZISWAF is used as an alternative solution to loyal problems that occur in the community, especially in times of crisis such as the covid-19 outbreak. Stakeholders can make ZISWAF an important instrument in improving food security and make it one of the important elements in improving the welfare of the community in meeting their food needs. The author hopes that the public will be increasingly aware of the importance of ZISWAF in economic life both in a safe and crisis situation. Allah has provided such 
a complete solution in the teachings of Islam. In addition to being a form of obedience to Allah SWT by carrying out His commands also as a form of help among others that will improve social and economic relations both in the community and the state.

\section{Zakat}

Zakat etymologically comes from the Arabic word zaka which means holiness grows or brings blessings (Hafidhuddin, 1998: 13). And in sharia terminology according to qardhawi defines zakat is a term for a number of assets issued that have reached nisab or dose and haul or a certain period of time with certain requirements and to certain people who are their rights and have been narrated by Allah SWT (Qardhawi, 1996). So it can be known that zakat is an obligation for agnia as stated in the 3rd pillar of Islam after the shahada and prayer so that it becomes one of the points of Islam that not only connects between humans with Allah SWT, but also strengthens relations between fellow humans by eliminating economic and social inequality so as to strengthen the relationship of friendship between human beings or religious people.

\section{Infaq}

As for infaq in the language of the word nafaqa which has the meaning of giving treasure. In terminology it can be defined as an act of worship to Allah SWT and the social charity of the community and humanity in handing over some of the property owned to others in need (Arfawie, 2005: 18). According to sharia infaq is defined as issuing some property or income for social purposes recommended by Islamic teachings. Here there is a difference with zakat, where zakat must be clear nishab and haul while in infaq there is no need for nisab and haul, after not required on every Muslim so that in the factor one can exchange it at any time without any limit of dose and time of issuing it (Hafidhuddin, 1998).

\section{Shodaqoh}

Shodaqoh according to etymology comes from the word shodaqoh which can be defined as giving a Muslim to others sincerely and voluntarily without being limited by a certain amount of time and amount (Hafidhuddin, 1998: 15). In this case alms has a wider meaning than infak and zakat because alms can not only be done by issuing material in the form of treasure or maal, but can also be a speech or kalam in the form of good advice or warning and deeds or deeds in the form of help in the form of energy and mind for those in need (Muhyidin, 2007: 7).

\section{Waqf}

The last part in ZISWAF is Waqf, colloying from the words $\mathrm{Al} \mathrm{Habsyu}$ and $\mathrm{Al}$ Man'u which means to restrain and prevent. Waqf can be interpreted as holding something that is used to benefit from something. In terms of waqf is to hold the property and drain its benefits in the way of Allah SWT, where the property is retained ownership but can be taken advantage of for the common good. Currently waqf empowerment has been implemented productively because it is realized the magnitude of the potential of waqaf when managed productively. This eliminates the thought of the people who used to treasure waqf in the form of land and buildings can only be used as mosques or used as airy land for tombs. 


\section{RESEARCH METHODS}

This research is qualitative research and falls into the category of libraryresearch. It is called qualitative because the nature of the data collected is not quantitative and does not use statistical measuring tools.

This study summarizes all findings about food security in the literature that serves as a source of research on the same topic. Collecting data on food security and food crises in the past, noting several problems about food security and solutions in maintaining food security then looking for alternative solutions according to islamic views and making it a comprehensive policy in maintaining food security in times of crisis. Literature research focuses on data sources in the form of books, journals, reports and other writings.

The main sources used in this study are quranic verses, hadiths and books related to ZISWAF, journals of food security and their problems and journals of public policy, public finance and fiscal policy based on Islamic economics. The data is collected by documentation techniques, namely by reading, reviewing, studying, and recording literature that has to do with the problems discussed in this article. Therefore, it is necessary to re-analyze the data that has been clarified. The goal is to find new findings that later became the focus in this study.

The method used to process the data in this study is a descriptive - analytical method, namely investigation and telling and interpreting existing data. Descriptive methods are not limited to the collection and preparation of data but include analysis and interpretation of the meaning of the data.

\section{RESULTS OF ANALYSIS}

Wishful thinking according to law no. 7 of 1996 is everything that comes from biological and water sources, whether processed or unprocessed, which are intended as food or beverages for human consumption, including food additives, food raw materials, and other materials used in the process of preparing, processing, and or making food or beverages. What is meant by food security according to Law no. 18 of 2012 is the condition of food fulfillment for the country up to individuals, which is reflected in the availability of sufficient food, both in number and quality, safe, diverse, nutritious, equitable, and affordable and not contrary to the religion, beliefs, and culture of the community, to be able to live healthy, active, and productive in a sustainable manner. On a world scale, FAO (2010) estimates that more than 900 million of the world's population will still be at risk of hunger and food insecurity. This is because currently food not only serves as food but also the raw materials of the biofuel industry so that there is competition in its use.

The food crisis that occurs in every decade becomes a threat to human survival. This crisis causes hunger and multidimensional conflicts that can undermine a country's security resilience. The absence of food supply can be caused by various factors such as drought, fuel scarcity, economic instability, war, and others. History proves that the food security crisis has left many communities devastated. Food crises have occurred in Athens and Rome, in China and Egypt (Republika.co.id 2014). Even in the time of the prophet Joseph (p.S.) when his family came to ask for his brother who had been taken prisoner. As mentioned in QS Joseph verse 88 . 
Ibn Kathir explained that when they came to the prophet Joseph (p.S.) in a state of drought and lack of food. So that the goods they bring are of poor quality.

Islam views the availability of food as a community right that must be fulfilled because it is included in the primary needs. In the principle of Maqosyid Shariah there are 5 things that must be maintained in humans; religion, soul, reason, treasure, descendants. Food goes into the guarding part of the soul or can even be associated with religion, reason, wealth and ancestry if it is associated with the consequences of food absence. The food security system in an Islamic perspective includes the guarantee of the fulfillment of basic food needs, food availability and food affordability by individual communities, as well as state food independence. The Prophet (peace be upon him) said the Son of Adam had no rights to this type: the house he lived in, the clothes that covered his awrah and the fresh bread and water (H.R. at-Tirmidhi).

Islam commands each individual to work for a living in order to meet his personal and family needs. As Allah says in QS Al-Baqoroh verse 233.

The fulfillment of basic needs is regulated in law no. 7 of 1996 and perfected by law no. 18 of 2012. The concept of Islamic Welfare is in accordance with QS AlQuraysh: 1-4 which includes: Islamic Value System, Economic Strength in trade and Industry, Fulfillment of Basic Needs and Distribution, and Security and Social Order.

The state must ensure that the community has the ability to access their food needs in this case the state guarantees the availability of jobs and ensures the implementation of sharia law on property ownership, management and development and ensures the implementation of market mechanisms in accordance with sharia so that the distribution of food needs is not hampered. In 17 sustainable development goals mentioned among them prevent hunger and these goals can be achieved by maintaining food security properly. The process of food availability from production, storage, distribution to consumption is comprehensively regulated in Islam. Islam strictly prohibits withholding the resources that many people need because it will damage market mechanisms. Allah (SWT) says in QS At-Taubah verse 34.

Food availability is closely related to the agrobusiness sector and its derivatives. This sector becomes the main center in food procurement in a region. Indonesia with a tropical landscape that has very fertile agricultural potential should be independent in terms of food. But when compared to a small Singapore without agricultural land that only relies on imports is very far in terms of food security. Man is sent to the face of the earth as caliph to purify the earth as the word of Allah SWT in QS Al Baqoroh verse 30 .

This verse describes the task of man being sent to the following earth with the vices that exist in him. This becomes a challenge for man when the noble task he carries intersects with the bad nature that exists in him such as damaging and shedding blood. In terms of food production, for example, humans often damage the environment to achieve large amounts of production by using excess pesticides for example. It does not pay attention to the future of humans who live in the future. Although in fact humans are given discretion in carrying out their economic activities including agriculture. As in the hadith of The 
Companions of Anas RA about mating dates. Once the Prophet passed by his companions who were marrying dates. Then he asked, "What is this?" The companions replied, "In this way, dates are good, O Messenger of Allah!" He said, "If you had not done so, it would have beengood." After he said that, they did not marry the dates again, but the dates became ugly. When he saw such a result, the Prophet asked why the date could be so ugly like this? They said, "O Messenger of Allah, you have told us this and so..." Then he said, "You know better the affairs of your world." (HR. Muslim, no. 2363)

Production is the process of creating wealth by exploiting existing natural resources. Food is everything sourced from animals and plants that are processed for consumption directly or in the process first. The richness of flora and fauna is a natural wealth that can continue to be renewed as long as humans maintain their ecosystems properly. Allah created plants and animals to be used as food so that humans could carry out their duties to worship Him. As the word of Allah SWT in QS Abasa verses 24-32 and QS An -Nahl verses 5-8.

If the production goes well and in line with what is expected, then the next is how to store and distribute it. In terms of food storage, Islam explains clearly in the Qur'an. Allah swt tells the story of prophet Yusuf (as) who gave takwil the king's dream as a form of food management in QS Yusuf verses 47-49 with three main things that Prophet Joseph taught in this verse is to increase food productivity, post-harvest management and a simple and frugal lifestyle.

The next process in maintaining food security is distribution. Distribution is the process of transferring a product from producer to consumer either directly or through an intermediary. Food distribution is also heavily influenced by infrastructure such as viable transportation lines so as not to hinder. Because as is known food is a product that has a time limit of use let alone food that is not processed. The market that is the center of distribution of food products must be maintained and considered the balance of prices and supplies. Often cheating in the distribution process becomes the beginning of damaged prices and scarcity of goods. Islam strongly prohibits price manipulation by preventing producers from coming to market and cutting distribution lines. This is commonly done by middlemen by buying cheaply from farmers then selling at high prices in the market. Setting prices for no apparent reason is prohibited in Islam, this is commonly done in the monopoly system. It is narrated in a hadith that the Prophet (peace be upon him) was asked to set a price but the Prophet refused.

In terms of consumption Islam provides a benchmark on halal and Toyib. Halal substance or how to get it has the same position in each individual. But Toyib is different from each other. This has implications for excessive prohibition and waste. In terms of food it is enough for humans to fill one-third of their stomach contents with food and not excess. As the Prophet said: There is no vessel filled by a man worse than his stomach, it is enough for him to eat a few mouthfuls to lift his backbone, so if he does not want to, then he can fill his stomach with one-third of his food, one-third drink and one third for his breath." [HR Ahmad] 


\section{DISCUSSION}

In times of crisis food conditions can vary. Sometimes the reserves are enough for each individual but are not reached by the community. This can be because the distribution line is cut off so that prices in certain regions soar so that people cannot afford it. Or it's not enough for every individual. Some areas can't get it. Indonesia is a fairly vast island nation this is an anecdote how the price of imported cattle is cheaper than the price of local cattle. Similarly, the cost of shipping (importing) rice from neighboring countries is cheaper than the cost of shipping local rice to the northern region of Sumatra.

Food consumption dominates the expenditure of Indonesian people. Even food consumption becomes the standard poverty limit. Food problems in Indonesia are more about the inability of the community in providing allocation of funds for their food needs. There is nothing but poverty that makes it difficult for society in terms of allocation of funds. The crisis is becoming more and more when unemployment is rampant. The government's obligation to provide assistance so that people can access their needs. The Central Bureau of Statistics (BPS) noted that the poverty rate as of March 2020 had increased to 26.42 million people. With this position, the percentage of poor people as of March 2020 also rose to 9.78 percent. Compared to March 2019, the increase reached 1.28 million people from 25.14 million people.

BAPPENAS said that the fulfillment of decent food needs is still a problem for the poor. In general, the difficulty of food fulfillment is caused by (1) low purchasing power, (2) inefficient trading, and (3) difficulty in food stocks in some areas that occur in certain seasons. The problem of food adequacy is not only related to food production, but also the problem of increasing income because the majority of poor farmers have to buy their groceries. Factors associated with the increase in the number and percentage of poor people during the period 2014-2015 included the increase in rice prices. In March 2015, food commodities that contributed the largest amount to the Poverty Line both in urban and rural areas were generally the same, such as rice which contributed 23.49 percent in urban areas and 32.88 in rural areas (SUSENAS, 2015).

ZISWAF in improving food availability and accessibility in times of crisis

ZISWAF became an important instrument of the country's fiscal policy in every generation of Islamic power. According to Yusoff (2002) Zakat can be one of the Fiscal instruments by regulating its division. At a time when the economy is booming, zakat is received more and issued less otherwise in a recession, zakat expenditure is increased, because at times of recession the number of unemployed increases, so does the poor. On the contrary, at a time when the economy is booming.

According to Metwally (1995), investments in Islamic economic countries have criteria: Hoarding Idle Assets, sanctions for holders of less / unproductive assets, a kind of tax for idle funds, Prohibited from doing various forms of speculation and all kinds of gambling, the interest rate for various kinds of loans is zero and instead used a revenue sharingsystem. If zakat is a mandatory sector in the distribution of property then infak, almsgiving and waqf is a voluntary sector. waqf in some countries has improved the welfare of people such as 
Palestine which develops waqf for education and Saudi Arabia with waqf on behalf of Uthman Bin Affan RA which until now the results of date garden waqf continue to be enjoyed by hajj pilgrims.

Economic downturn in a country will result in a lot of unemployment and poverty that has an impact on the difficulty of meeting their basic needs such as food. In islamic economics ZISWAF is an important component in terms of fighting poverty. Alleviation of poverty and partisanship to the weak is one of the missions of the Islamic economy. This mission is reflected in every branch of Islamic economic science and practice such as in banking, finance, business, and others. Included in the fiscal policy of the country in this case is the public finances. Indonesia has considerable potential to make ZISWAF a fiscal instrument. The potential of ZISWAF is able to be a source of development funds in meeting the basic needs of the community, especially food such as the agricultural sector and plantations. In the results of the Zakat Potential Mapping Index study conducted by PUSKAS BAZNAS, it was noted that in 2018 the potential of zakat in Indonesia reached 233 trillion rupiah or reached 3 percent of Indonesia's GDP and as much as 12.5 percent was zakat from the food industry, namely agriculture and livestock. But the collection of zakat only reached 8.2 trillion rupiah or comparable to 3.4 percent of the potential collection of zakat nationally. Meanwhile, according to the Indonesian Waqf Agency (BWI) has the potential of waqf assets in Indonesia reaching 2000 trillion rupiah with a total waqf land area of 420 thousand hectares. While the potential waqf money reaches 180 trillion rupiah. But in 2017, the collection of new waqf funds reached 400 billion rupiah.

Seeing the potential of zakat and waqf is so great, it should be used as an instrument in economic development, especially in areas that already have a system to apply zakat widely. Because in fact national development can not only rely on the central government, but also requires the role of regional participation in optimizing the economic potential (Hasibuan 2016). The development of waqf land to be able to become a center of the food industry can absorb labor and provide a positive economic impact on the surrounding community. The development of waqf-based agricultural land conducted by the Pondok Modern Waqf Maintenance and Expansion Foundation (YPPWPM) Gontor Ponorogo is a concrete example in maximizing the potential of waqf land owned with an area of more than 12 million square meters spread across 24 regions (Nur Cahyo and Muqorobin 2019).

Productive zakat and waqf money can be used as a solution for the development of the people's economy by making it as business capital in the real sector. Economic development in the real sector has a positive effect on the absorption of labor that will reduce unemployment and poverty. Utilization of productive zakat and waqf money has been widely done by amil zakat institutions such as Dompet Peduli Umat Daarut Tauhiid (DPU DT) which develops the utilization of productive zakat in the field of MSMEs, agriculture and livestock. This utilization has an impact on increasing the income of people who participate in the program so that their purchasing power increases.

Indonesia is a country with a cultural basis gotong-royong and please help. This is 
very much in line with the teachings of Islam that order humans to help their struggling brothers. Infak and almsgiving are a form of help in Islam. Infak is always associated with wealth while alms has a wider meaning can be with treasure or deeds. In the digital era as it is today distance is not a barrier for a person to give alms. Ease in providing assistance through trusted institutions has become a trend in the community and is expected to be a sustainable lifestyle.

\section{CONCLUSION}

Islam commands people to help each other and care for each other in a state of joy and sorrow. This principle is applied in the concept of property distribution, namely Zakat, Infak, almsgiving and waqf (ZISWAF). Zakat is the 3rd pillar of Islam that focuses on the economic sector that is mandatory. Then continued with infak, almsgiving and waqf that is voluntary. In terms of food security ZISWAF can be an alternative to food security in times of crisis. Starting from the empowerment of farmers as the main profession in maintaining food security, then the empowerment of traders and markets as food distribution channels and consumer empowerment to be able to access food.

The rice field waqf movement can be a solution to reduce agricultural land in many areas due to pollution, land acquisition for development and others. This waqf movement can be initiated by the Indonesian waqf agency as a national waqf institution and the ministry of agriculture as an institution responsible for agriculture. The poor have major problems with land tenure and ownership, as well as uncertainty in the ownership and ownership of agricultural land. The lives of farmers depended heavily on their access to arable land and the mobilization ability of their family members to work on their farmland.

Development of waqf-based agriculture as which is done by pondok pesantren gontor. Waqf land or rice fields are managed together with the community with the Mukhabarah agreement which is a system of cooperation in agricultural land cultivation with the procurement of seeds from land owners in this case Nazir or Muzara'ah with the procurement of seeds by farmers and mutually agreed revenue sharing or the ijaroh (reasonable) system. So that unproductive waqf land can be developed into agricultural land. This development can also be done by providing capital to farmers who own land but have limited capital through a money waqf program or productive zakat with a musyarokah agreement with agreed revenue share so that agricultural sustainability is maintained.

The development of market endowments as a center of food trade as a means of facilitating food distribution and developing the economy of the people in the field of trade. Providing business capital to traders with mudharabah or musyarokah agreements with agreed revenue share and ijaroh (rent) agreements so that financial circulation in the community is maintained. And the development of supporting infrastructure to facilitate food distribution channels to maintain price stability and equitable distribution of food availability throughout the region.

The development of MSMEs through productive zakat and cash waqf as a means of opening jobs, especially in the field of food processing and agricultural products because the impact will be very broad with increasing demand in the food market. With this 
empowerment, people who have the ability to work can continue to be productive and can meet their basic needs. Because the main problem that is often faced by the poor is the difficulty of getting a job and limited business opportunities.

The movement of caring for others through zakat, infak and alms to help people who have limitations in working as during the covid-19 outbreak now. Many communities are being housed or cut off from livelihoods due to the closure of educational institutions and offices. With direct cash assistance or direct contributions in the form of sembako community is still able to meet its needs and economic circulation continues to run.

\section{REFERENCES}

A yuni, Isnaini Qurroti. 2018. "POLA KELOLA WAKAF DALAM UPAYA PEMBERDAYAAN EKONOMI BERBASIS PESANTREN (Studi Wakaf Pertanian Ubi Pada Lembaga Wakaf Ansor)." Jurnal Ilmiah Mahasiswa FEB 7(1).

Almakki, Arsyad. t.t. "KEBIJAKAN EKONOMI UMAR BIN KHATTAB | Almakki | Al Qalam: Jurnal Ilmiah Keagamaan dan Kemasyarakatan." Diambil $24 \quad$ September 2021 (https://jurnal.stiqamuntai.ac.id/index.php/alqalam/article/view/14).

Anon. t.t. "BKP - Kementan Prediksi Ketersediaan Pangan Aman hingga Akhir Tahun 2020." Diambil 23 September 2021

(http://bkp.pertanian.go.id/blog/post/ke mentan-prediksi-ketersediaan-panganaman-hingga-akhir-tahun-2020).
Aziz, Fathul Aminudin. 2018. "Hukum Denda Dalam Keuangan Publik Islam Di Indonesia." Al-Manahij: Jurnal Kajian Hukum Islam 12(2):313-28. doi: 10.24090/mnh.v12i2.1760.

Detik.com. 2020. "Tembus Rekor! 46 Perusahaan Raksasa Bangkrut Garagara Corona." Diambil 29 September 2021 (https://finance.detik.com/beritaekonomi-bisnis/d-5143179/tembusrekor-46-perusahaan-raksasa-bangkrutgara-gara-corona).

Donna, Duddy Roesmara. t.t. "PENERAPAN WAKAF TUNAI PADA LEMBAGA KEUANGAN PUBLIK ISLAMI PDF Free Download." Diambil 3 Oktober 2021 (https://docplayer.info/48393262Penerapan-wakaf-tunai-pada-lembagakeuangan-publik-islami.html).

Kompas.com. 2020. "6 Bantuan Pemerintah di Tengah Pandemi Corona, dari Kartu Prakerja hingga Pulsa Rp 400.000 Halaman all." KOMPAS.com. Diambil $9 \quad$ Oktober 2020 (https://www.kompas.com/tren/read/20 20/09/02/090500565/6-bantuanpemerintah-di-tengah-pandemi-coronadari-kartu-prakerja-hingga).

UU nomor 41 Tahun 2004 tentang Wakaf UU nomor 23 Tahun 2011 tentang Zakat 